\title{
Numerical Taxonomy Analysis of Mycobacterium africanum
}

\author{
HUGO L. DAVID, ' MARIE-THÉRESE JAHAN, ' ARLETTE JUMIN,' JANINE GRANDRY,' \\ AND EGIL H. LEHMAN ${ }^{2}$
}

Service de la Tuberculose et des Mycobactéries, Institut Pasteur, Paris, ${ }^{1}$ and Institutt for Samfunnsmedisin, Universitet I Tromsø, Norway ${ }^{2}$

\begin{abstract}
A numerical taxonomy analysis of Mycobacterium africanum strains from Rwanda (6 strains), Burundi (5 strains), Yaoundé (23 strains), Dakar (17 strains), and Mauretania (9 strains) indicated that these bacteria did not cluster separate from the $M$. tuberculosis or the $M$. bovis clusters, nor did they eliminate the phenetic discontinuity between the latter. However, the African strains introduced considerable heterogeneity in the usually homogeneous $M$. tuberculosis and $M$. bovis clusters. Judging from the data, it did not seem justifiable to create a new species $M$. africanum. Preliminary genetic analysis did not support the view expressed earlier that these bacteria mutated at high frequencies, and further genetic analysis of these bacteria seemed necessary.
\end{abstract}

Mycobacterium africanum Castets, Boisvert and Rist, 1969 (2) is a group of mycobacteria reported to be phenotypically intermediate between $M$. bovis and $M$. tuberculosis. The characters in common with the latter species were not constant features in strains of $M$. africanum; instead, the numerous strains investigated appeared to fill the phenetic discontinuity between $M$. bovis and $M$. tuberculosis $(1,2,6,7,15-18$, 20). These observations led Prat et al. (18) to suggest that the earlier classification of the tubercle bacilli, i.e., $M$. tuberculosis and its human and bovine varieties, might be reestablished and completed by newer varieties such as the African variety of tubercle bacilli. Because the distinction between $M$. bovis and $M$. tuberculosis has more than academic interest (9), we decided to reexamine the taxonomic status of $M$. africanum.

\section{MATERIALS AND METHODS}

Bacterial strains. The 98 strains of mycobacteria assembled for this investigation are listed in Table 1. Two strains each of M. fortuitum, M. avium, M. kansasii, M. microti, and $M$. xenopi were included as controls. The type or neotype strains for each of the species were included in the study.

Numerical taxonomy analysis. The tests performed on the 98 strains are indicated in Table 2. Each strain was given a code number, and the study was conducted blind. Computer analysis was carried out as recommended by Lockhart and Liston (13). Methods and strain data have been deposited with the World Data Center for Microorganisms from which they may be obtained by interested readers.

Population analysis. For the purpose of examining the genetic variation in $M$. africanum, one strain from Rwanda was arbitrarily chosen. $M$. tuberculosis and $M$. bovis were used for comparison. The fluctuation test (14) and the study of variants in the popula- tions were performed as described previously $(3,22)$ and below.

\section{RESULTS}

Numerical taxonomy. The dendrogram shown in Fig. 1 was obtained excluding all strains of African origin. The strains belonging to known species, except for one strain labeled $M$. microti in our collection, separated into well defined clusters. The $M$. bovis and $M$. tuberculosis clusters separated at an $85 \%$ level of similarity. From the data, the properties of the hypothetical median strain (HMS) of $M$. bovis and M. tuberculosis were obtained, and all strains from these species were then compared to the HMS. The histogram (see Fig. 3A) represents the comparison of the $M$. bovis and $M$. tuberculosis strains with the M. tuberculosis HMS, and it indicates that the two species formed well separated and homogeneous clusters. These results indicated that the test character states selected for this investigation were satisfactory.

When the African strains were added in the analysis, we obtained the dendrogram shown in Fig. 2 and the histogram shown in Fig. 3B. The introduction of the African strains caused a 5\% downward displacement of the M. bovis-M. tuberculosis intertaxon value (Fig. 1 compared with Fig. 2), and a slight overlap of heterologous organisms (Fig. 3B compared with Fig. 3A). The histogram in Fig. 3B is distinctly bimodal, and the observed displacement is not sufficient to exclude the African strains from either the $M$. bovis or the $M$. tuberculosis taxon.

The distribution of the characters with greatest resolving power between clusters $F$ and $G$ is shown in Table 3. The examination of Table 3 clearly shows that the distribution of characters 
TABLE 1. List of strains used in this study

\begin{tabular}{|c|c|c|c|c|c|c|}
\hline \multirow{2}{*}{$\begin{array}{l}\text { Serial } \\
\text { no. }\end{array}$} & \multirow{2}{*}{$\begin{array}{l}\text { Lab } \\
\text { no. }\end{array}$} & \multicolumn{2}{|c|}{ Received as: } & \multirow{2}{*}{ Source $^{a}$} & \multirow{2}{*}{ Habitat } & \multirow{2}{*}{ Phenon } \\
\hline & & Name & Strain & & & \\
\hline 1 & 8144 A & $\begin{array}{l}\text { Mycobacterium } \\
\text { fortuitum }\end{array}$ & ATCC 6841 & ATCC & Type strain & A \\
\hline 2 & 5194 & $M$. fortuitum & HB 1792 & P. Coletsos & Sputum & A \\
\hline 3 & 5911 & M. avium & ATCC 15769 & ATCC & Type strain & B \\
\hline 4 & 3897 & M. avium & ATCC 15985 & ATCC & & B \\
\hline 5 & 7043 & M. kansasii & ATCC 12478 & ATCC & & $\mathrm{C}$ \\
\hline 6 & 7959 & M. kansasii & Hoks & H. Boisvert & Sputum & $\mathrm{C}$ \\
\hline 7 & 1840 & M. xenopi & Schwabacker & P. Hauduroy & Undetermined & $\mathrm{D}$ \\
\hline 8 & 0068 & M. xenopi & Lanhantec & H. Boisvert & Sputum & $\mathrm{D}$ \\
\hline 9 & 2627 & M. microti & OV 168 & Oxford vole & Undetermined & $\mathbf{E}$ \\
\hline 10 & 9910 & $M$. microti & Rotterdam & Unknown & Hog & $\mathrm{G}$ \\
\hline 11 & 1174 & M. tuberculosis & H $37 \mathrm{Rv}$ & Trudeau Inst. & Type strain & $\mathbf{F}$ \\
\hline 12 & 7838 & M. tuberculosis & HB 7838 & B. Lange (1931) & $\begin{array}{l}\text { Military tuberculosis } \\
\text { (Lubeck incident) }\end{array}$ & $\mathbf{F}$ \\
\hline 13 & 1899 & M. tuberculosis & Ham C-23 & H. Boisvert & Pleuritis & $\mathrm{F}$ \\
\hline 14 & 8108 & M. tuberculosis & Lirersky & H. Boisvert & Sputum & $\mathrm{F}$ \\
\hline 15 & 3337 & M. tuberculosis & Delfosse & H. Boisvert & Sputum & $\mathbf{F}$ \\
\hline 16 & 6006 & M. tuberculosis & Tanguy & H. Boisvert & Sputum & $\mathrm{F}$ \\
\hline 17 & 2500 & M. tuberculosis & HB 3863 & J. Grosset & Sputum & $\mathbf{F}$ \\
\hline 18 & 1845 & M. tuberculosis & HB 0212 & H. Boisvert & Undetermined & $\mathbf{F}$ \\
\hline 19 & 9731 & M. tuberculosis & Szabo 98 & I. Szabo & Undetermined & $\mathrm{F}$ \\
\hline 20 & $8144 \mathrm{C}$ & M. tuberculosis & Szabo 89 & A. Tacquet & Undetermined & $\mathbf{F}$ \\
\hline 21 & 0164 & M. bovis & ATCC 19210 & ATCC & Type strain & G \\
\hline 22 & 9222 & M. bovis & HB 1844 & G. Canetti & Sputum & G \\
\hline 23 & 2062 & M. bovis & HB 2582 & Vallée & Cat & $\mathbf{G}$ \\
\hline 24 & 1905 & M. bovis & HB 3439 & CDC & Monkey & G \\
\hline 25 & 3142 & M. bovis & HB 6966 & H. Boisvert & Undetermined & G \\
\hline 26 & 8372 & M. bovis & HB 3313 & H. Boisvert & Undetermined & $\mathrm{G}$ \\
\hline 27 & 5374 & M. bovis & Barthelemy & H. Boisvert & Meningitis & $\mathrm{G}$ \\
\hline 28 & 4043 & M. bovis & HB 3882 & H. Boisvert & Undetermined & $\mathrm{G}$ \\
\hline 29 & 0517 & M. bovis & HB 3625 & H. Boisvert & Sputum & $\mathrm{G}$ \\
\hline 30. & 7553 & M. bovis & HB 3513 & H. Boisvert & Sputum & $\mathbf{G}$ \\
\hline 31 & 3393 & M. bovis & HB 3889 & H. Boisvert & Undetermined & G \\
\hline 32 & 2680 & M. bovis & HB 6712 & H. Boisvert & Undetermined & G \\
\hline 33 & 4298 & M. bovis & HB 1849 & H. Boisvert & Undetermined & G \\
\hline 34 & 6271 & M. bovis & HB 1573 & H. Boisvert & Undetermined & G \\
\hline 35 & 8638 & M. bovis & HB 1864 & H. Boisvert & Undetermined & G \\
\hline 36 & 1736 & M. bovis & Neveu & H. Boisvert & Cow & G \\
\hline 37 & 7791 & M. bovis & HB 7199 & H. Boisvert & Undetermined & $\mathrm{G}$ \\
\hline 38 & 9380 & $M$. bovis & HB 2571 & P. Vergez & Sputum & $\mathrm{G}$ \\
\hline 39 & 8916 & M. africanum & RT 6833 & Rwanda & Sputum & $\mathbf{F}$ \\
\hline 40 & 2596 & M. africanum & RT 6856 & Rwanda & Sputum & $\mathrm{F}$ \\
\hline 41 & 6749 & M. africanum & RT 6854 & Rwanda & Sputum & $\mathbf{F}$ \\
\hline 42 & 2617 & M. africanum & RT 6832 & Rwanda & Sputum & $\mathbf{F}$ \\
\hline 43 & 6204 & M. africanum & RT 6862 & Rwanda & Sputum & $\mathbf{F}$ \\
\hline 44 & 0131 & M. africanum & RT 8834 & Burundi & Sputum & $\mathbf{F}$ \\
\hline 45 & 8726 & M. africanum & RT 8829 & Burundi & Sputum & $\mathbf{F}$ \\
\hline 46 & 2523 & M. africanum & RT 8818 & Burundi & Sputum & $\mathbf{F}$ \\
\hline 47 & 0010 & M. africanum & RT 8815 & Burundi & Sputum & $\mathbf{F}$ \\
\hline 48 & 0063 & M. africanum & RT 8811 & Burundi & Sputum & $\mathbf{F}$ \\
\hline 49 & 2315 & M. africanum & RT 5901 & Yaoundé & Sputum & $\mathbf{G}$ \\
\hline 50 & 0554 & M. africanum & RT 6619 & Yaoundé & Sputum & $\mathbf{G}$ \\
\hline 51 & 1487 & M. africanum & RT 6615 & Yaoundé & Sputum & $\mathrm{G}$ \\
\hline 52 & 4336 & M. africanum & RT 6899 & Yaoundé & Sputum & $\mathrm{G}$ \\
\hline 53 & 4954 & M. africanum & RT 6465 & Yaoundé & Sputum & G \\
\hline 54 & 0709 & M. africanum & RT 6464 & Yaoundé & Sputum & G \\
\hline 55 & 4331 & M. africanum & RT 6378 & Yaoundé & Sputum & $\mathbf{F}$ \\
\hline 56 & 6157 & M. africanum & RT 6467 & Yaoundé & Sputum & $\mathbf{G}$ \\
\hline 57 & 3135 & M. africanum & RT 6470 & Yaoundé & Sputum & G \\
\hline 58 & 5704 & M. africanum & RT 5897 & Yaoundé & Sputum & $\mathrm{G}$ \\
\hline
\end{tabular}


TABLE 1.-Continued

\begin{tabular}{|c|c|c|c|c|c|c|}
\hline \multirow{2}{*}{$\begin{array}{c}\text { Serial } \\
\text { no. }\end{array}$} & \multirow{2}{*}{$\begin{array}{l}\text { Lab } \\
\text { no. }\end{array}$} & \multicolumn{2}{|c|}{ Received as: } & \multirow{2}{*}{ Source $^{a}$} & \multirow{2}{*}{ Habitat } & \multirow{2}{*}{ Phenon } \\
\hline & & Name & Strain & & & \\
\hline 59 & 0924 & M. africanum & RT 611 & Yaoundé & Sputum & G \\
\hline 60 & 9795 & M. africanum & RT 6003 & Yaoundé & Sputum & $\mathrm{G}$ \\
\hline 61 & 5350 & M. africanum & RT 6114 & Yaoundé & Sputum & $\mathrm{G}$ \\
\hline 62 & 1112 & M. africanum & RT 6010 & Yaoundé & Sputum & $\mathrm{G}$ \\
\hline 63 & 5901 & M. africanum & RT 6002 & Yaoundé & Sputum & $\mathrm{G}$ \\
\hline 64 & 4310 & M. africanum & RT 6737 & Yaoundé & Sputum & G \\
\hline 65 & 5032 & M. africanum & RT 5895 & Yaoundé & Sputum & $\mathrm{G}$ \\
\hline 66 & 9224 & M. africanum & RT 6014 & Yaoundé & Sputum & $\mathrm{G}$ \\
\hline 67 & 7433 & M. africanum & RT 6137 & Yaoundé & Sputum & $\mathrm{G}$ \\
\hline 68 & 8717 & M. africanum & HB 3657 & Yaoundé & Sputum & $\mathbf{G}$ \\
\hline 69 & 0495 & M. africanum & HB 3656 & Yaoundé & Sputum & $\mathrm{G}$ \\
\hline 70 & 3623 & M. africanum & HB 3807 & Yaoundé & Sputum & $\mathrm{G}$ \\
\hline 71 & 2837 & M. africanum & RT 5900 & Yaoundé & Sputum & G \\
\hline 72 & 2329 & M. africanum & HB 5222 & Yaoundé & Sputum & $\mathrm{G}$ \\
\hline 73 & 7210 & M. africanum & ATCC 25420 & Dakar & Sputum & $\mathrm{G}$ \\
\hline 74 & 8948 & M. africanum & HB 1702 & Dakar & Sputum & $\mathrm{G}$ \\
\hline 75 & 7819 & M. africanum & HB 2048 & Dakar & Sputum & $\mathrm{G}$ \\
\hline 76 & 9226 & M. africanum & HB 2827 & Dakar & Sputum & $\mathrm{G}$ \\
\hline 77 & 3712 & M. africanum & HB 1659 & Dakar & Sputum & $\mathrm{G}$ \\
\hline 78 & 0559 & M. africanum & HB 1699 & Dakar & Sputum & $\mathrm{G}$ \\
\hline 79 & 8144 B & M. africanum & RT 8458 & Dakar & Sputum & G \\
\hline 80 & 8865 & M. africanum & RT 6088 & Dakar & Sputum & $\mathrm{G}$ \\
\hline 81 & 3442 & M. africanum & RT5273 & Dakar & Sputum & $\mathrm{G}$ \\
\hline 82 & 2595 & M. africanum & RT 8455 & Dakar & Sputum & G \\
\hline 83 & 0744 & M. africanum & RT 8456 & Dakar & Sputum & $\mathrm{G}$ \\
\hline 84 & 9854 & M. africanum & RT 6807 & Dakar & Sputum & $\mathrm{G}$ \\
\hline 85 & 0971 & $M$. africanum & RT 6091 & Dakar & Sputum & $\mathrm{G}$ \\
\hline 86 & 6882 & M. africanum & RT 8454 & Dakar & Sputum & $\mathrm{G}$ \\
\hline 87 & 3317 & M. africanum & RT 5272 & Dakar & Sputum & $\mathrm{G}$ \\
\hline 88 & 2549 & M. africanum & RT 8432 & Dakar & Sputum & $\mathrm{G}$ \\
\hline 89 & 1288 & M. africanum & RT 8982 & Mauretania & Sputum & $\mathrm{G}$ \\
\hline 90 & 9373 & M. africanum & RT 8945 & Mauretania & Sputum & $\mathrm{G}$ \\
\hline 91 & 7262 & M. africanum & RT 8967 & Mauretania & Sputum & G \\
\hline 92 & 6102 & M. africanum & RT 8946 & Mauretania & Sputum & G \\
\hline 93 & 9783 & M. africanum & RT 8935 & Mauretania & Sputum & $\mathrm{G}$ \\
\hline 94 & 1132 & M. africanum & RT 8966 & Mauretania & Sputum & $\mathrm{G}$ \\
\hline 95 & 7548 & M. africanum & RT 8970 & Mauretania & Sputum & $\mathrm{G}$ \\
\hline 96 & 5550 & M. africanum & RT 8974 & Mauretania & Sputum & $\mathrm{G}$ \\
\hline 97 & 1603 & M. africanum & RT 8985 & Mauretania & Sputum & $\mathrm{G}$ \\
\hline 98 & 2693 & M. africanum & RT 8980 & Mauretania & Sputum & $\mathrm{G}$ \\
\hline
\end{tabular}

${ }^{a}$ ATCC, American Type Culture Collection, Rockville, Md.; CDC, Center for Disease Control, Atlanta, Ga.

in clusters $F$ and $G$ from dendrogram 1 is homogeneous, whereas the distribution of characters in the same clusters from dendrogram 2 is rather heterogeneous. Therefore, although the African strains did not eliminate the phenetic discontinuity that justifies the separation of the species $M$. bovis from $M$. tuberculosis, they introduced considerable heterogeneity in both taxa.

Subclusters in cluster $F$ (from dendrogram 2). Subcluster $F_{1}$ was composed by one strain from Szabö ("green" strains) and one strain from Boisvert that was identified by him before as of the Szabö type. Subcluster $F_{2}$ con- tained three strains from Rwanda, two from Burundi, and one from Yaoundé. Subcluster $F_{3}$ contained seven strains of $M$. tuberculosis including the neotype strain ATCC 27294, one strain from Rwanda, and two strains from $\mathrm{Bu}$ rundi.

Subclusters in cluster $G$ (from dendrogram 2). Subcluster $G_{1}$ contained four strains from Yaoundé, two from Dakar, and one from Mauretania. Subcluster $G_{2}$ contained fourteen strains from Yaoundé, four strains from Mauretania, two strains from Dakar, one strain from Rwanda, and one strain of $M$. bovis. Subcluster $\mathrm{G}_{3}$ contained four strains from Yaoundé, thir- 
teen strains from Dakar, four strains from Mauretania, one strain labeled $M$. microti Rotterdam, and seventeen strains of $M$. bovis. The neotype strain $M$. bovis ATCC 19219 and the type strain $M$. africanum ATCC 25420 were included in this last subcluster.

Comparison of the HMS with the type or neotype strains of $M$. bovis, $M$. tuberculosis, and $M$. africanum. The comparison of the characters of the neotype or type strains with the characters of the HMS strains of $M$. tuber- culosis and $M$. bovis (Table 4) showed that there was complete agreement between $M$. tuberculosis ATCC 27294 and $M$. tuberculosis HMS. M. bovis ATCC 19210 differed from $M$. bovis HMS in two characters, and $M$. africanum ATCC 25420 differed from the $M$. bovis HMS strain in three characters.

Geographic distribution. The distribution of the African strains that clustered in the $M$. bovis taxon and in the M. tuberculosis taxon in respect to their geographic origin is depicted in

TABle 2. Properties exhibited by $M$. bovis, $M$. tuberculosis, and the strains in clusters $F$ and $G$ from the dendrogram shown in Fig. 2

\begin{tabular}{|c|c|c|c|c|c|}
\hline \multirow{2}{*}{ Character } & \multirow{2}{*}{ M. tuberculosis } & \multirow{2}{*}{ M. bovis } & \multicolumn{3}{|c|}{ Clusters } \\
\hline & & & $\mathrm{F}$ & & G \\
\hline Bacilli (2 $\mu \mathrm{m}$ long) & $+(100)$ & $+(100)$ & $+(100)$ & & $(100)$ \\
\hline Coccobacilli ( $2 \mu \mathrm{m}$ long) & $0(0)$ & $0(0)$ & $0(0)$ & 0 & (0) \\
\hline Cording & $+(71)$ & $0(0)$ & $0 \cdot(43)$ & 0 & (46) \\
\hline \multicolumn{6}{|l|}{ Growth at $37^{\circ} \mathrm{C}:$} \\
\hline 7 days or less & $0 \quad(0)$ & $0(0)$ & $0(0)$ & 0 & (0) \\
\hline Greater than 7 days & $+(100)$ & $+(100)$ & $+(100)$ & + & $(100)$ \\
\hline \multicolumn{6}{|l|}{ Colony type: ${ }^{a}$} \\
\hline Smooth S, T, D or I & $0 \quad(0)$ & $0(0)$ & $0(0)$ & 0 & (0) \\
\hline Rough R & $+(52)$ & $+(82)$ & $0(41)$ & 0 & (38) \\
\hline Rough $\mathbf{R}_{\mathrm{s}}$ & $0 \quad(29)$ & $0(47)$ & $0(15)$ & 0 & (29) \\
\hline Rough $R_{w}$ & $0 \quad(43)$ & $0(6)$ & $0 \quad(24)$ & 0 & (10) \\
\hline Rough Robb & $0(29)$ & $0(0)$ & $0(21)$ & 0 & (23) \\
\hline Lebek niveau ${ }^{b}$ & $0 \quad(10)$ & $+(88)$ & $0(26)$ & + & (87) \\
\hline Pigment in dark ${ }^{c}$ & $0(0)$ & $0(0)$ & $0(0)$ & 0 & (0) \\
\hline Pigment in light ${ }^{c}$ & $0(0)$ & $0(0)$ & $0(0)$ & 0 & (0) \\
\hline \multicolumn{6}{|l|}{ Growth temperature } \\
\hline $20^{\circ} \mathrm{C}$ & $0(0)$ & $0(0)$ & $0(0)$ & 0 & (0) \\
\hline $30^{\circ} \mathrm{C}^{d}$ & $+(100)$ & $+(100)$ & $+(100)$ & + & $(100)$ \\
\hline $37^{\circ} \mathrm{C}$ & $+(100)$ & $+(100)$ & $+(100)$ & + & $(100)$ \\
\hline $42^{\circ} \mathrm{C}$ & $0(0)$ & $0(0)$ & $0(0)$ & 0 & (0) \\
\hline $52^{\circ} \mathrm{C}$ & $0(0)$ & $0(0)$ & $0(0)$ & 0 & (0) \\
\hline Growth stimulation by pyruvate ${ }^{e}$ & $0(0)$ & $+(100)$ & $0(48)$ & + & (100) \\
\hline Growth on nutrient agar & $0(0)$ & $0(0)$ & $0(0)$ & 0 & (0) \\
\hline Acid from fructose & $0(0)$ & $0(0)$ & $0(0)$ & 0 & (0) \\
\hline $5 \% \mathrm{NaCl}$ tolerance & $0(0)$ & $0(0)$ & $0(0)$ & 0 & (0) \\
\hline Nitrite inhibition $(25 \mathrm{mM})^{f}$ & $+(100)$ & $+(100)$ & $+(100)$ & + & $(100)$ \\
\hline Niacin $^{g}$ & $+(100)$ & $0(0)$ & $+(86)$ & 0 & (21) \\
\hline \multicolumn{6}{|l|}{ Catalase: ${ }^{c}$} \\
\hline $40 \mathrm{~mm}$ or less bubbles & $+(100)$ & $+(100)$ & $+(100)$ & + & (100) \\
\hline $40 \mathrm{~mm}$ or more bubbles & $0(0)$ & $0(0)$ & $0(0)$ & 0 & (4) \\
\hline After heating at $68^{\circ} \mathrm{C}$ & $0(0)$ & $0(0)$ & $0(0)$ & 0 & $(0)$ \\
\hline \multicolumn{6}{|l|}{ Peroxidase: $^{h}$} \\
\hline Room temp & $+(100)$ & $+(100)$ & $+(100)$ & + & (100) \\
\hline After heating at $68^{\circ} \mathrm{C}$ & $0(0)$ & $0(0)$ & $0(0)$ & 0 & (0) \\
\hline Nitrate red (Tacquet) ${ }^{i}$ & $+(100)$ & $0(0)$ & $+(100)$ & 0 & (30) \\
\hline Nitrate red (Virtanen) ${ }^{c}$ & $+(100)$ & $0(0)$ & $+(81)$ & 0 & (4) \\
\hline Nitrite red (Tacquet) ${ }^{i}$ & $0(14)$ & $0(0)$ & $0(5)$ & 0 & $(0)$ \\
\hline Acid phosphatase & $+(100)$ & $+(94)$ & $+(81)$ & + & (66) \\
\hline Alkaline phosphatase ${ }^{k}$ & $+(100)$ & $+(94)$ & $\begin{array}{l}+(62) \\
+(61)\end{array}$ & 0 & $(43)$ \\
\hline Tween hydrolysis ${ }^{l}$ & $0(14)$ & $0(0)$ & $0(5)$ & 0 & (3) \\
\hline Urease $^{m}$ & $+(100)$ & $+(76)$ & $+(95)$ & 0 & (26) \\
\hline Arylsulfatase $^{c}$ & $0(0)$ & $0(0)$ & $0(0)$ & 0 & (0) \\
\hline$\beta$-Glucosidase ${ }^{n}$ & $+(100)$ & $0(0)$ & $0(43)$ & 0 & (1) \\
\hline Pyrazinamidase $^{\circ}$ & $+(100)$ & $0(0)$ & $+(95)$ & 0 & (6) \\
\hline
\end{tabular}


TABLE 2.-Continued

\begin{tabular}{lllll}
\hline & & & & Clusters \\
\cline { 4 - 5 } Character & & M. bovis & F & G \\
\hline Growth in presence of: ${ }^{p}$ & & & & \\
INH $(0.1 \mu \mathrm{g} / \mathrm{ml})$ & $0(0)$ & $0(0)$ & $0(0)$ & $0(0)$ \\
TCH $(2.0 \mu \mathrm{g} / \mathrm{ml})$ & $+(100)$ & $0(0)$ & $+(81)$ & $0(0)$ \\
PZA $(400.0 \mu \mathrm{g} / \mathrm{ml})$ & $0(29)$ & $+(88)$ & $0(14)$ & $0(24)$ \\
Tb $(2.0 \mu \mathrm{g} / \mathrm{ml})$ & $0(0)$ & $0(0)$ & $0(0)$ & $0(31)$ \\
PAS $(0.5 \mu \mathrm{g} / \mathrm{ml})$ & $0(0)$ & $0(7)$ & $0(0)$ & $0(4)$ \\
SM $(4.0 \mu \mathrm{g} / \mathrm{ml})$ & $0(0)$ & $0(0)$ & $0(0)$ & $0(1)$ \\
EMB $(2.0 \mu \mathrm{g} / \mathrm{ml})$ & $0(0)$ & $0(0)$ & $0(0)$ & $0(0)$ \\
D-CS $(30.0 \mu \mathrm{g} / \mathrm{ml})$ & $0(0)$ & $0(0)$ & $0(0)$ & $0(0)$ \\
RIF $(40.0 \mu \mathrm{g} / \mathrm{ml})$ & $0(0)$ & $0(0)$ & $0(0)$ & $0(0)$ \\
KAN $(20.0 \mu \mathrm{g} / \mathrm{ml})$ & $0(0)$ & $0(0)$ & $0(0)$ & $0(0)$ \\
VM $(30.0 \mu \mathrm{g} / \mathrm{ml})$ & $0(0)$ & $0(0)$ & $0(0)$ & $0(0)$ \\
CAP $(40.0 \mu \mathrm{g} / \mathrm{ml})$ & $0(0)$ & $0(0)$ & $0(0)$ & $0(0)$ \\
ETH $(20.0 \mu \mathrm{g} / \mathrm{ml})$ & $0(0)$ & $0(0)$ & $0(0)$ & $0(8)$ \\
\hline
\end{tabular}

${ }^{a}$ All strains gave rough colonies. Colony types S, T, D, and I are as described by Vestal (21). Abbreviations: rough $R$, rough with coarse cords; $R_{s}$, rough with central button; $R_{w}$, rough, dark, and compact; and $R_{0 b b}$ rough, opaque, and with folded edges.

${ }^{b}$ Lebek (12).

c Vestal (21).

${ }^{d}$ All strains grew at $30^{\circ} \mathrm{C}$, but growth was poor.

e Castets et al. (1).

${ }^{f}$ Kestle, Abbott, and Kubica (10).

Eiacin test strip (Difco).

${ }^{h}$ Boisvert, personnal communication.

'Tacquet and Tison (19).

j Kapler (8).

${ }^{k}$ David (4).

${ }^{l}$ Tween hydrolysis substrate (Difco).

${ }^{m}$ Urea-indole, Pasteur. About $10.0 \mathrm{mg}$ of cells was suspended in $1.0 \mathrm{ml}$ of the substrate. The mixture was incubated overnight at $37^{\circ} \mathrm{C}$; development of a red color indicated a positive reaction.

${ }^{n}$ David and Jahan (5).

${ }^{\circ}$ About $10.0 \mathrm{mg}$ of cells was suspended in $1.0 \mathrm{ml}$ of a $10^{-3} \mathrm{M}$ solution of pyrazinamide in tris(hydroxymethyl)aminomethane buffer (Sigma), $\mathrm{pH}$ 7.2. The mixture was incubated overnight at $37^{\circ} \mathrm{C}$, when the presence of pyrazonoic acid was determined by the addition of crystals of ferrous ammonium sulfate.

${ }^{p}$ In Lowenstein-Jensen medium. Abbreviations: INH, isoniazid; TCH, thiophencarboxylic acid hydrazide; PZA, pyrazinamide; $\mathrm{Tb}_{1}$, amithiazone; PAS, $p$-amino salicylic acid; SM, streptomycin; EMB, ethambutol; D-CS, D-cycloserine; RIF, rifampin; KAN, kanamycin; VM, viomycin; CAP, capreomycin; ETH, ethionamide.

TABLE 3. Distribution of characters with greatest resolving power between $M$. bovis and $M$. tuberculosis, between clusters $G$ and $F$ from Fig. 2, and within clusters $G$ and $F$

\begin{tabular}{|c|c|c|c|c|c|c|c|c|c|c|}
\hline \multirow{2}{*}{ Test } & \multirow{2}{*}{ M. bovis } & \multirow{2}{*}{$\begin{array}{l}\text { M. tuber- } \\
\text { culosis }\end{array}$} & \multicolumn{2}{|c|}{ Cluster } & \multicolumn{6}{|c|}{ Subcluster } \\
\hline & & & F & G & $\mathrm{G}_{1}$ & $\mathrm{G}_{2}$ & $\mathrm{G}_{3}$ & $\mathbf{F}_{1}$ & $\mathbf{F}_{2}$ & $F_{3}$ \\
\hline Lebek niveau & 100 & 0 & 87 & 26 & 83 & 71 & 90 & 0 & 29 & 22 \\
\hline $\begin{array}{l}\text { Growth stimulation } \\
\text { by pyruvate }\end{array}$ & 100 & 0 & 100 & 48 & 100 & 100 & 100 & 0 & 71 & 30 \\
\hline Niacin & 0 & 100 & 21 & 86 & 100 & 50 & 16 & 100 & 71 & 70 \\
\hline Nitrate red (Tacquet) & 0 & 100 & 30 & 100 & 100 & 100 & 24 & 100 & 100 & 100 \\
\hline Nitrate red (Virtanen) & 0 & 100 & 4 & 81 & 100 & 0 & 16 & 100 & 57 & 100 \\
\hline Acid phosphatase & 94 & 100 & 66 & 81 & 71 & 68 & 64 & 100 & 50 & 100 \\
\hline Alkaline phosphatase & 94 & 100 & 43 & 62 & 43 & 41 & 44 & 100 & 0 & 90 \\
\hline Urease & 76 & 100 & 26 & 95 & 71 & 18 & 38 & 100 & 100 & 100 \\
\hline$\beta$-Glucosidase & 0 & 100 & 1 & 43 & 100 & 0 & 0 & 100 & 0 & 60 \\
\hline Pyrazinamidase & 0 & 100 & 6 & 95 & 0 & 0 & 7 & 100 & 100 & 100 \\
\hline \multicolumn{11}{|l|}{ Growth in presence of: ${ }^{a}$} \\
\hline TCH $(2.0 \mu \mathrm{g} / \mathrm{ml})$ & 0 & 100 & 0 & 81 & 0 & 0 & 0 & 100 & 86 & 100 \\
\hline PZA $(400.0 \mu \mathrm{g} / \mathrm{ml})$ & 88 & 29 & 24 & 14 & 0 & 0 & 27 & 33 & 0 & 20 \\
\hline $\mathrm{Tb}_{1}(2.0 \mu \mathrm{g} / \mathrm{ml})$ & 0 & 0 & 31 & 0 & 71 & 50 & 13 & 0 & 0 & 0 \\
\hline
\end{tabular}

\footnotetext{
${ }^{a}$ Abbreviations: TCH, thiophencarboxylic acid hydrazide; PZA, pyrazinamide; $\mathrm{Tb}_{1}$, amithiazone.
} 


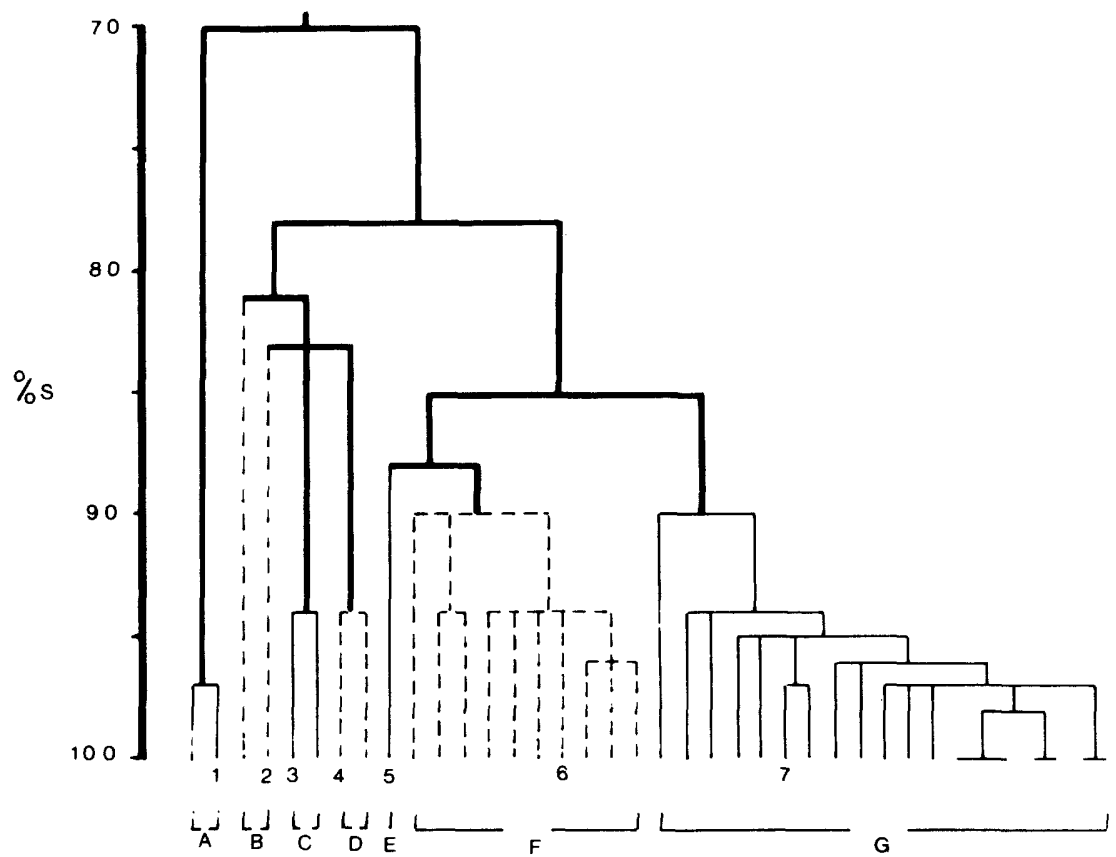

Fig. 1. Dendrogram of 38 mycobacteria selected with intended bias to assess the taxonomic value of the chosen tests. Cluster A, M. fortuitum; cluster B, M. avium; cluster $C, M$. kansasii; cluster D, M. xenopi; cluster $E, M$. microti; cluster $F, M$. tuberculosis; and cluster $G, M$. bovis. Strain $1, M$. fortuitum ATCC 1792; strain 2, M. avium ATCC 15769; strain 3, M. kansasii ATCC 12478; strain 4, M. xenopi ATCC 19276; strain 5, M. microti, Oxford vole 168; strain 6, M. tuberculosis ATCC 27294; and strain 7, M. bovis ATCC 19210.

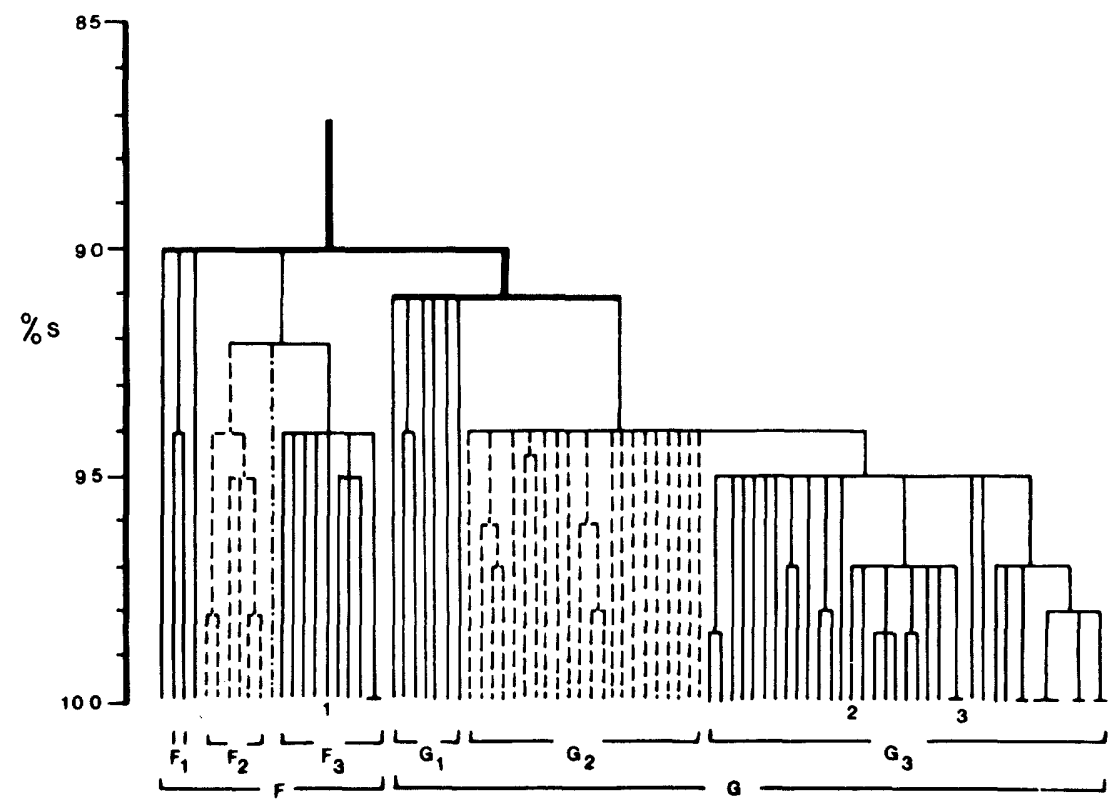

Fig. 2. Dendrogram of 89 strains of $M$. tuberculosis, $M$. bovis, and $M$. africanum. Cluster $F_{1}, M$. tuberculosis; cluster $G_{1}, M$. bovis. In addition to $M$. tuberculosis, cluster $F$ contained 6 strains from Rwanda, 5 strains from Burundi, and 1 strain from Yaoundé; in addition to $M$. bovis, cluster $G$ contained 22 strains from Yaoundé, 17 strains from Dakar, 9 strains from Mauretania, and 1 strain labeled $M$. microti Rotterdam. For the distribution of the strains in the recognizable subclusters, see Table 5. Strain 1, M. tuberculosis ATCC 27294; strain 2, M. bovis ATCC 19210; strain 3, M. africanum ATCC 25420. 

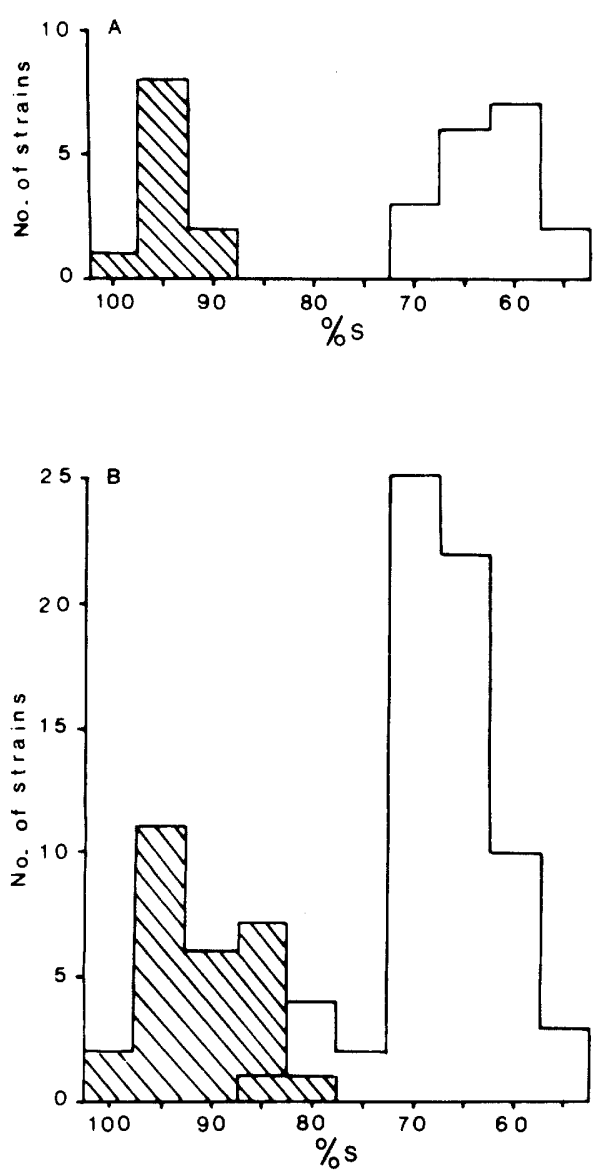

FIG. 3. Histograms obtained by comparing all strains in clusters $F$ and $G$ with the hypothetical medium strain of $M$. tuberculosis. (A) Strains in clusters $F$ and $G$ from dendrogram in Fig. $1 ;(B)$ strains in clusters $F$ and $G$ from dendrogram in Fig. 2.
Table 5. All strains except one from West Africa (Yaoundé, Dakar, and Mauretania) were in the $M$. bovis cluster $\mathrm{G}$, and all strains except one from Rwanda and Burundi were in the $M$. $t u$ berculosis cluster $\mathrm{F}$.

Genetic variation. The phenetic analysis described above excluded $M$. africanum as a distinct species, and suggested that the African strains are variants of either $M$. bovis or $M$. tuberculosis. It was reported earlier (18) that the African strains mutate at high frequencies which could explain the heterogeneity introduced by these strains in the $M$. bovis and $M$. tuberculosis clusters. The mutation rates of a strain from Rwanda from sensitivity towards resistance to isoniazid, streptomycin, rifampin, and kanamycin did not differ significantly from the correspondent mutation rates in $M$. bovis and $M$. tuberculosis (Table 6). On the other hand, these bacteria exhibited considerable variation in results in the various tests shown in Table 7. These data, therefore, excluded mutator effects in the strain but indicated a genetic phenomenon that requires further examination.

\section{DISCUSSION}

Our data showed conclusively that the African strains of tubercle bacilli did not segregate into a cluster separate from $M$. bovis or $M$. tuberculosis, leading us to question the validity of the species $M$. africanum Castets, Boisvert and Rist, 1969. Furthermore, our data did not lend support to the proposal that the African strains are intermediate organisms linking $M$. bovis and $M$. tuberculosis in a single species and several varieties (18). The African strains clustered with either $M$. bovis or $M$. tuberculosis, and although they introduced in $M$. tuberculosis considerable

TABLE 4. Reactions of the HMS of M. tuberculosis and the neotype strain ATCC 27294 (11), and the HMS of $M$. bovis, the neotype strain ATCC 19210 (9), and the type strain ATCC 25420 of M. africanum (2)

\begin{tabular}{|c|c|c|c|c|c|}
\hline \multirow{2}{*}{ Test } & \multicolumn{2}{|c|}{ M. tuberculosis } & \multicolumn{3}{|c|}{ M. bovis } \\
\hline & HMS & ATCC 27294 & HMS & ATCC 19210 & ATCC 25420 \\
\hline Lebek niveau & 0 & 0 & + & + & + \\
\hline Growth stimulation by pyruvate & 0 & 0 & + & + & + \\
\hline Niacin & + & + & 0 & 0 & 0 \\
\hline Nitrate reductase (Tacquet) & + & + & 0 & 0 & 0 \\
\hline Nitrate reductase (Virtanen) & + & + & 0 & 0 & 0 \\
\hline Acid phosphatase & + & + & + & + & + \\
\hline Alkaline phosphatase & + & + & + & 0 & 0 \\
\hline Urease & + & + & + & 0 & 0 \\
\hline$\beta$-Glucosidase & + & + & 0 & 0 & 0 \\
\hline Pyrazinamidase & + & + & 0 & 0 & 0 \\
\hline \multicolumn{6}{|l|}{ Growth in presence of: ${ }^{a}$} \\
\hline $\mathrm{TCH}(2.0 \mu \mathrm{g} / \mathrm{ml})$ & + & + & 0 & 0 & 0 \\
\hline PZA $(400.0 \mu \mathrm{g} / \mathrm{ml})$ & 0 & 0 & + & + & 0 \\
\hline $\mathrm{Tb}_{1}(2.0 \mu \mathrm{g} / \mathrm{ml})$ & 0 & 0 & 0 & 0 & 0 \\
\hline
\end{tabular}

${ }^{a}$ Abbreviations: TCH, thiophencarboxylic acid hydrazide; PZA, pyrazinamide; $\mathrm{Tb}_{1}$, amithiazone. 
heterogeneity, the phenetic discontinuity between the two taxa was not eliminated. It may be argued, however, that the observed (albeit slight) downward displacement in the intertaxon value might have been more apparent, or per-

TABLE 5. Distribution of the African strains in the $M$. bovis taxon and in the $M$. tuberculosis taxon, in respect to their geographic origin

\begin{tabular}{|c|c|c|c|c|c|c|}
\hline \multirow{2}{*}{$\begin{array}{l}\text { Geographic } \\
\text { origin }\end{array}$} & \multicolumn{3}{|c|}{$\begin{array}{c}M . \text { bovis } \\
\text { taxon (cluster G) }\end{array}$} & \multicolumn{3}{|c|}{$\begin{array}{l}\text { M. tuberculosis } \\
\text { taxon (cluster F }\end{array}$} \\
\hline & $\mathrm{G}_{1}$ & $\mathrm{G}_{2}$ & $\mathrm{G}_{3}$ & $F_{1}$ & $\mathrm{~F}_{2}$ & $\mathbf{F}_{3}$ \\
\hline Rwanda & 0 & 1 & 0 & 0 & 3 & 1 \\
\hline Burundi & 0 & 0 & 0 & 0 & 2 & 2 \\
\hline Yaoundé & 4 & 14 & 4 & 0 & 1 & 0 \\
\hline Dakar & 2 & 1 & 13 & 0 & 0 & 0 \\
\hline Mauretania & 1 & 4 & 4 & 0 & 0 & 0 \\
\hline
\end{tabular}

haps would have disappeared, had we used a much larger number of strains in our study. In this respect it was interesting that the African strains clustered according to their geographic origin. Most strains from West Africa clustered in the $M$. bovis cluster $\mathrm{G}$, and the strains received from the more eastward region of Africa (Rwanda and Burundi) were found in the $M$. tuberculosis cluster F. Strains received from regions between these two extremes were not available for study.

Even if the study of many more strains might cause the clusters to fuse, the data implied a genetic diversity that requires clarification. The careful and detailed descriptions by Rist and his collaborators $(1,2,7,18)$ led them to suspect that these bacteria mutated at high frequencies. We tested this hypothesis by measuring the

TABLE 6. Mutation rates ( $\alpha$ ) from susceptibility towards resistance to the indicated drugs of $M$. tuberculosis, $M$. bovis, and a strain (RT 6858) from Rwanda

\begin{tabular}{|c|c|c|c|c|c|c|}
\hline \multirow{2}{*}{ Drug $^{\alpha}$} & \multicolumn{2}{|c|}{ M. tuberculosis } & \multicolumn{2}{|c|}{ M. bovis } & \multicolumn{2}{|c|}{ Rwanda RT 6858} \\
\hline & $\alpha$ & $\mathbf{M f}^{b}$ & $\alpha$ & Mf & $\alpha$ & Mf \\
\hline INH & $9 \times 10^{-8}$ & 6.92 & $1.3 \times 10^{-8}$ & 1.0 & $1.6 \times 10^{-7}$ & 12.3 \\
\hline STM & $7.1 \times 10^{-9}$ & 1.39 & $5.1 \pm 10^{-9}$ & 1.0 & $1.6 \times 10^{-8}$ & 3.1 \\
\hline RIF & $3.3 \times 10^{-8}$ & 1.32 & $2.5 \times 10^{-8}$ & 1.0 & $7.5 \times 10^{-8}$ & 3.0 \\
\hline KAN & $9.1 \times 10^{-9}$ & 0.95 & $9.6 \times 10^{-9}$ & 1.0 & $4.2 \times 10^{-8}$ & 4.4 \\
\hline
\end{tabular}

${ }^{a}$ The concentrations of isoniazid (INH), streptomycin (STM), rifampin (RIF), and kanamycin (KAN) were, respectively, $1.0 \mu \mathrm{g} / \mathrm{ml}, 2.0 \mu \mathrm{g} / \mathrm{ml}, 1.0 \mu \mathrm{g} / \mathrm{ml}$, and $5.0 \mu \mathrm{g} / \mathrm{ml}$.

${ }^{b} \mathrm{Mf}$, Mutation factor $=($ mutation rate of test organism $) /($ mutation rate of reference $)$. In these calculations, $M$. bovis was used as the reference organism.

TABLE 7. Phenotypes of clones, and subcultures, of strain RT 6858 of $M$. africanum (Rwanda)

\begin{tabular}{|c|c|c|c|c|c|c|c|}
\hline \multirow{2}{*}{$\begin{array}{c}\text { Test } \\
\text { condition }^{a}\end{array}$} & \multirow{2}{*}{$\begin{array}{l}\text { Pyruvate } \\
\text { stimulation }\end{array}$} & \multicolumn{2}{|c|}{ Nitrate reductase } & \multirow{2}{*}{$\begin{array}{l}\beta \text {-Gluco- } \\
\text { sidase }\end{array}$} & \multirow{2}{*}{ Niacin } & \multirow{2}{*}{$\begin{array}{l}\text { Pyrazin- } \\
\text { amidase }\end{array}$} & \multirow{2}{*}{$\begin{array}{l}\text { Growth } \\
\text { in the } \\
\text { presence } \\
\text { of } \mathrm{TCH}^{b}\end{array}$} \\
\hline & & Tacquet & Virtanen & & & & \\
\hline $\mathrm{A}^{1}$ & 40 & 100 & 45 & 0 & 100 & 45 & 99 \\
\hline$A^{2}$ & 61 & 100 & 69 & 7 & 92 & 46 & 100 \\
\hline $\mathrm{A}^{3}$ & 20 & 100 & 80 & 0 & 60 & 0 & 100 \\
\hline $\mathrm{A}^{4}$ & 38 & 100 & 69 & 0 & 100 & 23 & 100 \\
\hline \multirow[t]{6}{*}{$\mathbf{B}$} & 1 & & + & 0 & + & 0 & \\
\hline & 2 & & 0 & 0 & + & + & \\
\hline & 3 & & + & 0 & + & + & \\
\hline & 4 & & 0 & 0 & + & + & \\
\hline & 5 & & + & 0 & + & 0 & \\
\hline & 6 & & 0 & 0 & + & 0 & \\
\hline $\mathrm{C}$ & 0 & + & 0 & 0 & + & + & + \\
\hline
\end{tabular}

${ }^{a}$ Test condition A: Percent of positive clones in the indicated tests. $A^{1}=12$ colonies cloned from culture no. 3 in the fluctuation test; $A^{2}=13$ colonies cloned from culture no. 16 in the fluctuation test; $\mathrm{A}^{3}=10$ colonies cloned from isoniazid-containing plates in the fluctuation test; $A^{4}=13$ colonies cloned from kanamycincontaining plates in the fluctuation test. Test condition B: Growth on the surface and in the depth of Lebeck medium was carefully transferred to Lowenstein-Jensen slants. The cultures were allowed to grow, and the indicated tests were then performed as usual. (1) Parental strain, growth on the surface. (2) Parental strain, growth in depth. (3) Eugonic clone from RT 6858, growth on the surface. (4) Eugonic clone from RT 6858, growth in depth. (5) Dysgonic clone from RT 6858, growth on the surface. (6) Dysgonic clone from RT 6858, growth in depth. Test condition C: The parental strain RT 6858 was tested as usual. 
mutation rates towards resistance to drugs of a strain from Rwanda, and did not find evidence for mutator effects. Yet, the population analysis in respect to test results in biochemical tests showed variations at a frequency that cannot be explained by spontaneous mutations. Therefore, we think that the fundamental mechanism of the genetic instability of these organisms needs to be further investigated. Because we have observed that the genetic instability was found for some but not all of the test characters, we hypothesize that it may be caused by extrachromosomal genes. This hypothesis is now under investigation.

From a practical point of view, the differential identification of $M$. bovis and $M$. tuberculosis, where and when African strains must be identified, is complicated by the need to perform more laboratory tests than is usually recommended. According to our data, the minimal tests necessary to identify conclusively the two species are growth stimulation by pyruvate, niacin production, nitrate reductase, $\beta$-glucosidase, pyrazinamidase, and growth in the presence of thiophencarboxylic acid hydrazide. In our opinion strains that do not give the expected test results in one or more of the indicated tests must be further investigated.

\section{ACKNOWLEDGMENTS}

This work was supported by grants from the Comite National contre la Tuberculose et les Maladies Respiratoires and the Institut National de la Santé et de la Recherche Médicale.

\section{REPRINT REQUESTS}

Address reprint requests to: Dr. Hugo David, Service de la Tuberculose et des Mycobactéries, Institut Pasteur, 28 rue du Dr. Roux, Cedex 15 Paris, France.

\section{LITERATURE CITED}

1. Castets, M., H. Boisvert, F. Grumbach, M. Brunel, and N. Rist. 1968. Les bacilles tuberculeux de type africain (note préliminaire). Rev. Tuberc. Pneumol. 32:179-184.

2. Castets, M., N. Rist, and H. Boisvert. 1969. La variété africaine du bacille tuberculeux humain. Méd. Afr. Noire 16:321-322.

3. David, H. L. 1970. Probability distribution of drug resistant mutants in unselected populations of Mycobacterium tuberculosis. Appl. Microbiol. 20:810-814.

4. David, H. L. 1977. Alkaline phosphatases from Mycobacterium smegmatis. J. Gen. Microbiol. 101:99-102.

5. David, H. L., and M. T. Jahan. 1977. $\beta$-Glucosidase activity in mycobacteria. J. Clin. Microbiol. 5:383-384.
6. Hermans-Boveroulle, M. T., S. R. Pattyn, and F. Gatti. 1965. Etude de souches humaines de $M$. tuberculosis isolées à Léopoldville. Ann. Soc. Belge Méd. Trop. 45:531-540.

7. Huet, M., and N. Rist. 1973. Intérêt des milieux au pyruvate pour la culture du bacille tuberculeux en Af. rique Noire. Bull. Union Int. Cent. Tuberc. 48:97-101.

8. Kapler, W. 1965. Zur Differenzierung von Mykobacterien mit dem Phosphatase-Test. Beitr. Klin. Tuberk. Spezifischen Tuberk.-Forsch. 130:223-226.

9. Karlson, A. G., and E. F. Lessel. 1970. Mycobacterium bovis nom. nov. Int. J. Syst. Bacteriol. 20:273-282.

10. Kestle, D. G., V. D. Abbott, and G. P. Kubica. 1967. Differential identification of mycobacteria. II. Subgroups of group II and III (Runyon) with different clinical significance. Am. Rev. Respir. Dis. 95:1041-1052.

11. Kubica, G. P., T. H. Kim, and F. P. Dunbar. 1972 Designation of strain $\mathrm{H} 37 \mathrm{Rv}$ as the neotype strain of Mycobacterium tuberculosis. Int. J. Syst. Bacteriol. 22:99-106.

12. Lebek, G. 1959. Die Abhängigkeit des sauer Stoffoptimums der beiden Sangetiertypen des Mycobacterium tuberculosis von den angebotenen Nährstoffen. Zentralbl. Bakteriol. Parasitenkd. Infektionskr. Hyg. Abt. I Orig. 176:530-537.

13. Lockhart, W. R., and J. Liston (ed.). 1970. Methods for numerical taxonomy. American Society for Microbiology, Washington, D.C.

14. Luria, S. E., and M. Delbrück. 1943. Mutations of bacteria from virus sensitivity to virus resistance. Genetics 28:491-511.

15. Medeiros, D., M. Castets, and S. Diop. 1973. Aspects morphologiques comparés de Mycobacterium tuberculosis, type classique, et de Mycobacterium africanum (note préliminaire). Afr. Noire Lang. Franç. 18:477-484.

16. Meissner, G., and K. Schröder. 1969. Über sog. afrikanische Mykobacterien-Stämme aus dem tropischen West-Afrika. Zentralbl. Bakteriol. Parasitenkd. Infektionskr. Hyg. Abt. I Orig. 211:69-81.

17. Pattyn, S. R., F. Portaels, L. Spanoge, and J. Magos. 1970. Further studies on African strains of Mycobacte. rium tuberculosis. Comparison with $M$. bovis and $M$. microti. Ann. Soc. Belge Méd. Trop. 50:211-228.

18. Prat, R., N. Rist, N. Dumitrescu, A. Mugabushaka, S. Clavel, and C. Duponchel. 1974. Special characteristics of the cultures of tubercle bacilli isolated in Rwanda. Bull. Union Int. Cent. Tuberc. 49:53-62.

19. Tacquet, A., and F. Tison. 1966. Activité réductrice des mycobactéries sur le nitrite de sodium. Ann. Inst. Pasteur (Paris) 111:359-363.

20. Van den Groen, G., and S. R. Pattyn. 1975. Comparison of Mycobacterium africanum, $M$. tuberculosis and $M$. bovis by their utilization of carbon and nitrogen sources. Ann. Soc. Belge Méd. Trop. 55:647-651.

21. Vestal, A. 1975. Procedures for the isolation and identification of mycobacteria. DHEW publication no. (CDC) 76-8230. Center for Disease Control, Atlanta, Ga.

22. Woodley, C., and H. L. David. 1976. Effect of temperature on the rate of the transparent to opaque colony type transition in Mycobacterium avium. Antimicrob. Agents Chemother. 9:113-119. 